\title{
Utilization of Eupatorium (Chromoleana odorata), an obnoxious weed as green leaf manure in enhancing rice productivity
}

\author{
K. Manjappa \\ Agricultural Research Station (Paddy), Banavasi Road, Sirsi, Karnataka, India
}

\begin{abstract}
A field experiment was conducted during kharif seasons of 2002 and 2003 at Agricultural Research Station (Paddy), Sirsi to know the effect of eupatorium as green leaf manure in combination with graded levels of inorganic fertilizers on rice yield and profitability. On an average over two years, application of $100 \%$ recommended dose of fertilizer (RDF) recorded maximum grain yield, straw yield and net returns followed by $50 \%$ RDF and no fertilizer which were differing significantly from one another. The grain yield recorded with application of eupatorium @ $10 \mathrm{t} / \mathrm{ha}(6735 \mathrm{~kg} / \mathrm{ha})$ was found to be on par with that of $20 \mathrm{t} / \mathrm{ha}(6929 \mathrm{~kg} / \mathrm{ha})$ and $15 \mathrm{t} / \mathrm{ha}(6915 \mathrm{~kg} / \mathrm{ha})$. The trend in net returns was almost similar to that of grain yield. Whereas, the straw yield recorded with eupatorium @ $10 \mathrm{t} / \mathrm{ha}(6205 \mathrm{~kg} / \mathrm{ha})$ was found to be on par with that of $15 \mathrm{t} / \mathrm{ha}(6130 \mathrm{~kg} / \mathrm{ha})$ only. The data on interaction indicates that the grain yield and net returns recorded with combination of eupatorium@20t/ha+100\%RDF, eupatorium@15t/ha+100\%RDF, eupatorium@10 t/ha+100\% RDF, eupatorium@10 t/ha+50\%RDF and eupatorium@15 t/ha+50\%RDF.
\end{abstract}

Key Words: Eupatorium, fertilizer, grain yield, straw yield, returns,

\section{Introduction}

Eupatorium (Chromoleana odorata) an obnoxious weed found in abundance in the North Kanara district of Karnataka has become a menace in younger plantations, waste lands and along road sides. This weed is also known to cause diseases in animals and human beings [1]. Considering its adverse impact on the environment, several attempts have been made to control this weed by adopting various methods. But, none of the methods showed great promise in controlling this weed. Under this juncture, few efforts were made to find out alternate ways for controlling/minimizing this weed menace. One of the environmentally friendly ways to eradicate this weed would be its utilization for productive purposes in agriculture. One of the ways of using eupatorium is as green leaf manure before its seed setting [2]. Further, the N, P and $\mathrm{K}$ content of eupatorium is quite comparable to other conventional green manure crops like sunnhemp, and glyricidia [3]. Hence an effort has been made in this investigation to find out the effect of eupatorium as green leaf manure on rice productivity.

\section{Materials and Methods}

A field experiment was conducted during kharif seasons of 2002-03 and 2003-04 at Agricultural Research Station (Paddy), Sirsi to know the effect of eupatorium as green leaf manure in conjunction with inorganic fertilizers on productivity of paddy. The experiment was laid out in split plot design with three replications. The different levels of eupatorium (no eupatorium, eupatorium @ 5, 10,15 and 20 t/ha) were allotted to main plot treatments and the levels of inorganic fertilizers (no fertilizer, $50 \%$ and $100 \%$ RDF) to sub plots. The recommended dose of fertilizer (RDF) used for paddy was 75:75:87.5 kg N, $\mathrm{P}_{2} \mathrm{O}_{5}$ and $\mathrm{K}_{2} \mathrm{O}$ per ha. The fresh and succulent eupatorium was incorporated into the soil two weeks before planting as per the treatments. Before incorporation, the eupatorium was chopped into 2-3 pieces by using sickle. 25 days old seedlings of ruling rice variety Abhilash with duration of about 150-155 days were used for planting. The crop was grown as rainfed transplanted rice. In treatments having inorganic fertilizer levels, 50 per cent each of $\mathrm{N}$ and $\mathrm{K}$ and entire dose of $\mathrm{P}$ was applied as basal dose at the time of transplanting. The first top dressing was done with 25 per cent of $\mathrm{N}$ and remaining 50 per cent of $\mathrm{K}$ at 25 days after transplanting. The crop was second top dressed with remaining 25 per cent of $\mathrm{N}$ at 50 days after transplanting. The crop was harvested when it attained maturity and yield per ha was calculated based on the net plot yield. Based on the prevailing market prices, gross and net returns were worked out. The individual years and as well as pooled data was analyzed statistically as per the split plot design under M-STAT-C programme.

\subsection{Effect of inorganic fertilizers on grain and straw yield}

\section{Results and Discussion}

The grain and straw yields were influenced significantly by the application of different inorganic fertilizer levels during the both the years as well as in pooled data. During 2003 and in pooled data, application of $100 \%$ RDF recorded significantly higher grain yield (7507 and $7147 \mathrm{~kg} / \mathrm{ha}$, respectively) when compared to 50\% RDF 
(6626 and $6644 \mathrm{~kg} / \mathrm{ha}$, respectively) and no fertilizer (5614 and $5653 \mathrm{~kg} / \mathrm{ha})$. The results are in conformity with Katyal and Gangwar [4]. Whereas, in 2002, the grain yield recorded with $100 \% \mathrm{RDF}$ (6788 kg/ha) and 50\% RDF (6661 kg/ha) were on par but significantly superior over no fertilizer $(5691 \mathrm{~kg} / \mathrm{ha})$. The straw yield was maximum with application of $100 \% \mathrm{RDF}$ followed by 50\% RDF and no fertilizer during both the years as well as in pooled data (Table 1). The net returns realized with $100 \% \mathrm{RDF}$ and $50 \% \mathrm{RDF}$ were on par with each other but significantly superior over no fertilizer in individual years (Table 3). Whereas, in pooled data, these treatments are differing significantly from one another. This clearly indicates that the rice responds for higher level of fertilizer application.

\subsection{Effect of eupatorium on grain and straw yield}

The grain and straw yields were also influenced significantly by the application of different levels of eupatorium during both the years as well as in pooled data (Table 1). The grain yields recorded with application of eupatorium at $10 \mathrm{t} / \mathrm{ha}(6569,6900$ and $6735 \mathrm{~kg} / \mathrm{ha}$, respectively), $15 \mathrm{t} / \mathrm{ha}(6651,7180$ and $66915 \mathrm{~kg} / \mathrm{ha}$, respectively) and $20 \mathrm{t} / \mathrm{ha}(6487,7370$ and $6929 \mathrm{~kg} / \mathrm{ha}$, respectively) were found to be on par with each other during 2002, 2003 and in pooled data. The response of rice in terms of straw yield to application of eupatorium was different in different years. During both the years as well as in pooled data, the maximum straw yield was recorded with eupatorium @ 20 t/ha. However, the straw yield recorded with this level (eupatorium @ $20 \mathrm{t} / \mathrm{ha}$ ) was found to be on par with that of eupatorium at $10 \mathrm{t} / \mathrm{ha}(6132 \mathrm{~kg} / \mathrm{ha})$ during 2002 and with both $10 \mathrm{t} / \mathrm{ha}$ (6280 $\mathrm{kg} / \mathrm{ha})$ and $15 \mathrm{t} / \mathrm{ha}(6130 \mathrm{~kg} / \mathrm{ha})$ during 2003 . The trend in net returns realized with application of eupatorium was almost similar to that of grain yield (Table 3). This data clearly indicated that the response of rice was maximum up to 10 tonnes per ha of eupatorium. Thereafter, there was not much influence of eupatorium in increasing rice grain yield.

\subsection{Interaction effect of inorganic fertilizers and eupatorium}

The ' $F$ ' test indicates that the interaction effect of eupatorium levels and chemical fertilizers was found to be non significant with respect to grain and straw yield as well as gross and net returns. Similar results were obtained by Chandra and Pareek [5]. However, the DMRT test clearly indicates that there was significant difference in these parameters recorded with different combinations of inorganic fertilizer and eupatorium levels. On an average over two years, the maximum grain yield was recorded with combination of eupatorium @ $20 \mathrm{t} / \mathrm{ha}+100 \% \operatorname{RDF}(7582 \mathrm{~kg} / \mathrm{ha})$ and was found to be on par with that of eupatorium @ $15 \mathrm{t} / \mathrm{ha}+100 \%$ RDF (7555 kg/ha), eupatorium @ $10 \mathrm{t} / \mathrm{ha}+100 \%$ RDF (7327 kg/ha), eupatorium @ $10 \mathrm{t} / \mathrm{ha}+50 \% \mathrm{RDF}$ (7043 $\mathrm{kg} / \mathrm{ha}$ ) and eupatorium @ $15 \mathrm{t} / \mathrm{ha}+50 \% \mathrm{RDF}(7030 \mathrm{~kg} / \mathrm{ha})$ (Table 2). Similarly, the net returns realized with eupatorium @ 15 t/ha + 100\% RDF (Rs. 33977/ha), eupatorium @ 20 t/ha + 100\% RDF (Rs. 33346/ha), eupatorium @ 10 t/ha + 100\% RDF (Rs. 32708/ha), eupatorium @ 10 t/ha + 50\% RDF (Rs. 31448/ha) and eupatorium @ $15 \mathrm{t} / \mathrm{ha}+50 \%$ RDF (Rs. 30547/ha) were found to be on par with each other. This clearly indicates that inorganic fertilizers can be restricted to $50 \%$ if eupatorium is used as green manure even at $10 \mathrm{t} / \mathrm{ha}$ in combination with inorganic fertilizers. Salik Ram and Sanjoy Saha [6] recorded higher grain yield, straw yield, gross return and net return per rupee investment when different types of organics (farm yard manure, green manure and poultry manure) were applied with chemical fertilizer in 50:50 ratio compared to fertilizer alone. At Palampur, pooled analysis of rice over years indicated that 100\% dose of recommended NPK through fertilizers was on par with 50\% RDF plus 50\% nitrogen through green manure [7]. Raju and Reddy [8] recorded similar results on rice with the application of sesbania green leaf manure.

\section{Conclusions}

Escalating costs of inorganic fertilizers on one hand and their undesirable impacts on soil health on the other hand call for immediate inclusion of organic sources in crop production. At this juncture, the present study showed that eupatorium (Chromolaena odorata), an obnoxious weed found in abundance all along roadsides, waste lands and in forest area can be used as green leaf manure in rice cultivation as it was found to increase yield of rice.

\section{Acknowledgement}

The authors are grateful to ICAR for funding the project under NATP (CGP) Programme.

\section{References}

[1] M. M. Hosamani, Integrated weed management in field crops (Wood Ridge Hill Publication, Texas, 1995).

[2] M.S. Anwarulla, Eupatorium weed - a green manure for rice, The Hindu, Daily, dated. 2-5-1996.

[3] K. Manjappa, Sustainable production of planted and ratoon crop of hybrid rice under hill zone of Kanataka, doctoral diss., University of Agricultural Sciences, Dharwad, Karnataka, India, 1999.

[4] V. Katyal and B. Gangwar, Long-term effect of integrated nutrient management on crop productivity of rice (Oryza sativa) -rice system, Indian Journal of Agricultural Sciences, 70(2), 2000), 110-113. 
[5] R. Chandra and R.P. Pareek, Effect of different green manure crops on growth, yield and N uptake by rice, Oryza, 35(3), 1998, 256-259.

[6] Salik Ram and Sanjoy Saha, Economics of conjuctive use of organics and chemical feriltilizer in rice crop grown under low land situation, Oryza, 36(3), 1999, 286-287.

[7] V. Katyal, K.S. Gangwar, B. Gangwar and K.V. Anand, Assessment of long term effects of integrated nutrient supply on crop productivity and soil fertility in rice-wheat cropping system. Oryza, 39, 2002, 15-20.

[8] R.A. Raju and M.N. Reddy, Integrated management of green leaf, compost, crop-residues and inorganic fertilizers in rice (Oryza sativa) - rice system. Indian Journal of Agronomy, 45(4), 2000, 629-635.

Table 1: Effect of different levels of eupatorium and inorganic fertilizers on grain and straw yield of rice

\begin{tabular}{|c|c|c|c|c|c|c|}
\hline \multirow[t]{2}{*}{ Treatments } & \multicolumn{3}{|c|}{ Grain Yield (kg/ha) } & \multicolumn{3}{|c|}{ Straw yield(kg/ha } \\
\hline & 2002 & 2003 & Pooled & 2002 & 2003 & Pooled \\
\hline Inorganic Fertilizer levels & & & & & & \\
\hline No Fertilizer & 5691 & 5614 & 5653 & 5061 & 4746 & 4903 \\
\hline $50 \% \mathrm{RDF}$ & 6661 & 6626 & 6644 & 5770 & 5727 & 5748 \\
\hline $100 \% \mathrm{RDF}$ & 6788 & 7507 & 7147 & 6585 & 7001 & 6793 \\
\hline S.Em \pm & 95 & 199 & 110 & 160 & 210 & 132 \\
\hline C.D. at 5\% & 373 & 780 & 359 & 628 & 824 & 430 \\
\hline Organic Manures & & & & & & \\
\hline No eupatorium & 5958 & 5457 & 5707 & 4716 & 4584 & 4650 \\
\hline Eupatorium @ 5t/ha & 6235 & 6005 & 6120 & 5470 & 4983 & 5227 \\
\hline Eupatorium @10t/ha & 6569 & 6900 & 6735 & 6132 & 6280 & 6206 \\
\hline Eupatorium @ 15t/ha & 6651 & 7180 & 6915 & 5989 & 6271 & 6130 \\
\hline Eupatorium @ 20t/ha & 6487 & 7370 & 6929 & 6719 & 7005 & 6862 \\
\hline S.Em \pm & 133 & 177 & 111 & 213 & 284 & 178 \\
\hline C.D. at 5\% & 388 & 516 & 315 & 622 & $\mathbf{8 3 0}$ & 505 \\
\hline
\end{tabular}

Table 2: Interaction effect of eupatorium levels and inorganic fertilizers on grain and straw yield of rice (Average of two years; pooled)

\begin{tabular}{|l|c|c|c|c|c|c|}
\hline \multirow{2}{*}{$\begin{array}{c}\text { Organic Manures / Inorganic } \\
\text { fertilizer levels }\end{array}$} & \multicolumn{3}{|c|}{ Grain Yield (kg/ha) } & \multicolumn{3}{c|}{ Straw yield(kg/ha } \\
\cline { 2 - 7 } & No Fertilizer & $50 \%$ RDF & $100 \%$ RDF & No Fertilizer & $50 \%$ RDF & $100 \%$ RDF \\
\hline No eupatorium & 4780 & 5883 & 6459 & 3924 & 4500 & 5525 \\
\hline Eupatorium @ 5t/ha & 5229 & 6316 & 6814 & 4352 & 5365 & 5963 \\
\hline Eupatorium @ 10t/ha & 5834 & 7043 & 7327 & 5076 & 6300 & 7243 \\
\hline Eupatorium @ 15t/ha & 6161 & 7030 & 7555 & 4992 & 5643 & 7754 \\
\hline Eupatorium @ 20t/ha & 6258 & 6946 & 7582 & 6172 & 6932 & 7481 \\
\hline S.Em \pm & $\mathbf{1 9 2}$ & \multicolumn{3}{c|}{$\mathbf{3 0 8}$} \\
\hline C.D. at 5\% & NS & & \multicolumn{3}{c|}{} \\
\hline
\end{tabular}

Table 3: Effect of different levels of eupatorium and inorganic fertilizers on economics of rice

\begin{tabular}{|l|c|c|c|c|c|c|}
\hline \multirow{2}{*}{ Treatments } & \multicolumn{3}{|c|}{ Gross returns (Rs./ha) } & \multicolumn{3}{c|}{ Net returns (Rs./ha) } \\
\cline { 2 - 7 } & 2002 & 2003 & Pooled & 2002 & 2003 & Pooled \\
\hline $\begin{array}{c}\text { Inorganic Fertilizer levels } \\
\text { No Fertilizer }\end{array}$ & 36397 & 35625 & 36012 & 24053 & 23281 & 23667 \\
\hline 50\% RDF & 42404 & 42172 & 42288 & 28815 & 28583 & 28699 \\
\hline 100\% RDF & 43920 & 48287 & 46103 & 29087 & 33454 & 31271 \\
\hline \multicolumn{1}{|c|}{ S.Em \pm} & $\mathbf{4 3 6}$ & $\mathbf{1 2 4 2}$ & $\mathbf{6 5 8}$ & $\mathbf{4 3 6}$ & $\mathbf{1 2 4 2}$ & $\mathbf{6 5 8}$ \\
\hline C.D. at 5\% & $\mathbf{1 7 1 2}$ & $\mathbf{4 8 7 5}$ & $\mathbf{2 1 4 6}$ & $\mathbf{1 7 1 2}$ & $\mathbf{4 8 7 5}$ & $\mathbf{2 1 4 6}$ \\
\hline $\begin{array}{c}\text { Organic Manures } \\
\text { No eupatorium }\end{array}$ & 37544 & 34596 & 36071 & 24955 & 22008 & 23482 \\
\hline Eupatorium @ 5t/ha & 39761 & 38008 & 38885 & 26672 & 24920 & 25796 \\
\hline Eupatorium @ 10t/ha & 42262 & 44232 & 43247 & 28674 & 30643 & 29659 \\
\hline Eupatorium @ 15t/ha & 42569 & 45763 & 44165 & 28480 & 31674 & 30077 \\
\hline Eupatorium @ 20t/ha & 42400 & 47539 & 44969 & 27811 & 32950 & 30381 \\
\hline S.Em \pm & $\mathbf{8 7 7}$ & $\mathbf{1 1 5 0}$ & $\mathbf{7 2 3}$ & $\mathbf{8 7 7}$ & $\mathbf{1 1 5 0}$ & $\mathbf{7 2 3}$ \\
\hline C.D. at 5\% & $\mathbf{2 5 6 0}$ & $\mathbf{3 3 5 7}$ & $\mathbf{2 0 5 5}$ & $\mathbf{2 5 6 0}$ & $\mathbf{3 3 5 7}$ & $\mathbf{2 0 5 5}$ \\
\hline
\end{tabular}

Table 4: Interaction effect of eupatorium levels and inorganic fertilizers on economics of rice (Average of two years; pooled)

\begin{tabular}{|c|c|c|c|c|c|c|}
\hline \multirow{2}{*}{$\begin{array}{c}\text { Organic Manures / Inorganic } \\
\text { fertilizer levels }\end{array}$} & \multicolumn{3}{|c|}{ Gross returns (Rs./ha) } & \multicolumn{3}{|c|}{ Net returns (Rs./ha) } \\
\hline & No Fertilizer & $50 \% \mathrm{RDF}$ & $100 \% \mathrm{RDF}$ & No Fertilizer & $50 \% \mathrm{RDF}$ & $100 \%$ RDF \\
\hline No eupatorium & 30306 & 36855 & 41050 & 18962 & 24265 & 27217 \\
\hline Eupatorium @5t/ha & 33112 & 40105 & 43438 & 21268 & 27016 & 29105 \\
\hline Eupatorium @10t/ha & 37163 & 45037 & 47541 & 24819 & 31448 & 32708 \\
\hline Eupatorium @15t/ha & 38880 & 44307 & 49310 & 26037 & 30218 & 33977 \\
\hline Eupatorium @20t/ha & 40592 & 45136 & 49180 & 27248 & 30547 & 33346 \\
\hline S.Em \pm & \multicolumn{3}{|c|}{1252} & \multicolumn{3}{|c|}{1252} \\
\hline C.D. at 5\% & & & & & & \\
\hline
\end{tabular}

